\title{
Wheat Productivity and Nutrient Uptake after Inhibitory Soil Salinity Adverse by some Sulphur Sources
}

\author{
A. M. Helmy" and Kh. A. Shaban ${ }^{* *}$ \\ *Soil Science Department, Faculty of Agriculture, Zagazig \\ University, Zagazig and ${ }^{* *}$ Soil, Water and Environment \\ Research Institute, ARC, Giza, Egypt.
}

\begin{abstract}
A STUDY was conducted on a village 4, Gilbana town at Sahl El-Tina plain, North Sinai, Egypt during two successive winter seasons of 2011/2012 and 2012/2013, in order to investigate the influence of sulphur from different sources, i.e., gypsum (G) in two rates G1 and $\mathrm{G} 2$, 4 Mega gram $(\mathrm{Mg}) \mathrm{fed}^{-1}$ and $8 \mathrm{Mg} \mathrm{fed}^{-1}$, respectively as well as elemental sulphur (ES) and sulphuric acid (SA) as soil application on inhibitory the hazardous effects of soil salinity stress on vegetative growth, yield and its quality of new cultivar Masr 2 of wheat (Triticum aestivum cv.) grown on a salt affected soil irrigated with low quality water of El-Salam canal as well as some chemical characteristics of the experiment soil after harvest. The obtained results could be summarized as follows:

- The highest values of wheat yield and its attributes as well as grains quality was obtained under the treatment of sulphuric acid. Also, the highest nutrient content and uptake by wheat plants were obtained due to the same treatment.

- The effective of treatments showed a descending increase in the order of, sulphuric acid > elemental sulphur > gypsum, $8.0 \mathrm{Mg} \mathrm{fed}^{-1}$ $>$ gypsum $4.0 \mathrm{Mg} \mathrm{fed}^{-1}>$ control.

- Proline content gave the highest value $\left(18.4 \mu \mathrm{mol} \mathrm{g}^{-1}\right)$ under the treatment of gypsum at rate of $4.0 \mathrm{Mg} \mathrm{fed}^{-1}$ in a descending order gypsum, 4.0 $\mathrm{Mg} \mathrm{fed}^{-1}>$ gypsum, $8.0 \mathrm{Mg} \mathrm{fed}^{-1}>$ elemental sulphur > sulphuric acid $>$ control.

- Soil available N, P and K were increased due to application of different treatments over the control. The corresponding highest $\mathrm{N}$ and $\mathrm{K}$ values were 55.1 and $202 \mathrm{mg} \mathrm{kg}^{-1}$ soil, respectively and recorded under application of sulphuric acid while, it was $4.75 \mathrm{mg} \mathrm{P}$ $\mathrm{kg}^{-1}$ soil due to the treatment of $8 \mathrm{Mg}$ gypsum $\mathrm{fed}^{-1}$. The highest values of $\mathrm{Fe}, \mathrm{Mn}$ and $\mathrm{Zn}\left(2.92,2.41\right.$ and $0.85 \mathrm{mg} \mathrm{kg}^{-1}$ soil, respectively) were obtained due to sulphuric acid treatment. Soil $\mathrm{pH}$ and soil EC were decreased due to application of the treatments comparing to the control. The lowest soil $\mathrm{pH}$ and $\mathrm{EC}$ values (7.98 and $7.53 \mathrm{dS} \mathrm{m}^{-1}$, respectively) were obtained under sulphuric acid treatment.
\end{abstract}

Keywords: Saline soil, Gypsum, Sulphur, Wheat. 
Wheat (Triticum aestavium L.) is one of the most important cereal crops in Egypt. Wheat provides $37 \%$ of the total calories and $40 \%$ of the protein in the Egyptian people diet. Total production of wheat in Egypt reached 8.407 million tons in 2011, produced from an area of 3.058 million feddan (FAO, 2011). Recently, a great attention of several Egyptian investigators has been directed to increase the productivity of wheat to minimize the gap between the production and consumption through increasing land area productivity and increasing cultivated area.

Sahl El-Tina plain is a part of El-Salam Canal surrounding area was a case of saline soil under reclamation. The soil is highly saline in its original state. The agricultural policy was to use the low quality water of El-Salam canal in this region. The promising areas that should be irrigated with El- Salam canal about 620.000 feddan (Ministry of Public Works and Water Resources, 1998). It is worthy to mention that agriculture drainage water is one of the most important non-conventional water resources in Egypt that plays a major role in water plans and policies. Currently, about 5 milliard $\mathrm{m}^{3}$ of drainage water in the Nile Delta can be reused directly after mixing them with fresh water (El-Refaie and Fahmy, 2005). These waters may contain nutrients and organic materials being fertilizer sources (Mostafa, 2001).

Sulphur is one of the essential nutrients for plant growth and it accumulates 0.2 to $0.5 \%$ in plant tissue on dry matter basis. It is required in similar amount as that of phosphorus (De Kok et al., 2002 and Ali et al., 2008). It is a building block of protein and a key ingredient in the formation of chlorophyll (Duke and Reisenaue, 1986). It is one of major nutrients essential for plant growth, root nodule formation of legumes and plant protection mechanisms (Blake- Kalff et al., 2000).

Sulphuric acid is another amendment that can be applied for reclamation of saline sodic soils. In such soils, sulphuric acid can be used as an ameliorating element which reacts with calcite and provides a soluble source of calcium. Some studies on the amelioration of saline-sodic soils by application of sulphuric acid during crop growth period have pointed out the efficiency of sulphuric acid in soil crusting prevention (Amezketa et al., 2005) and in reclamation of salinesodic soils (Sadiq et al., 2007).

Gypsum is the most commonly used amendment in Egypt. Gypsum is a moderately soluble source of plants essential nutrients, calcium and sulphur (Dick et al., 2008). It can improve plant growth and improve the physical and chemical properties of soils primarily by maintaining a favorable soil solution electrolyte concentration. The results of studies have revealed that by the application of gypsum to saline-sodic and sodic soils, adsorbed sodium on the soil complex is being replaced by the calcium (Choudhary et al., 2011).

Chemical amendments have long been recognized as ameliorators of sodic soils. Many of these amendments include gypsum, sulphuric acid and sulphur

Egypt. J. Soil Sci. 53, No. 2 (2013) 
(Scherer, 2001, Zia et al., 2006, Sabir et al., 2007, Mazhar et al., 2011 and Bello, 2012), which have been found to be effective in ameliorating sodicity of soil.

The present study was undertaken to evaluate the impact of sulphur from different sources on soil fertility, yield and its components as well as nutrient content of a new wheat cultivar plants grown on a salt affected soil irrigated with El-Salam canal water.

\section{Material and Methods}

The study was conducted on a saline soil located in village No. 4 at Sahl ElTina plain in the east of Suez Canal, North Sinai Governorate for two successive winter seasons 2011/2012 \& 2012/2013, cultivated with new wheat cultivar (Triticium aestivum cv. Misr 2). The area is one of the new reclaimed soils and irrigated with El-Salam canal 1:1 mixture of agriculture drainage water and fresh water (Nile water). A representative soil sample $(0-30 \mathrm{~cm})$ was taken before planting to determine some physical, chemical and nutritional properties (Table 1). Irrigation water parameters during the two successive seasons of the experiment are recorded in Table 2. A complete randomized block design with three replicates, having a plot area $12 \times 13 \mathrm{~m}$, was used. Each plot was sown with grains of new wheat cultivar (Triticum aestivum cv. Misr 2) on the $2^{\text {nd }}$ and $5^{\text {th }}$ of November, 2011 and 2012 and harvested on the $21^{\text {th }}$ and $25^{\text {th }}$ of April, 2012 and 2013, respectively.

TABLE 1. Some physical and chemical properties of the soil used in the current study.

\begin{tabular}{|c|c|c|c|c|c|}
\hline \multicolumn{2}{|l|}{ Properties } & Values & Properties & $\mathbf{v}$ & ues \\
\hline \multicolumn{3}{|c|}{ Particle size distribution (\%) } & \multicolumn{3}{|c|}{ Available nutrients $\left(\mathrm{mg} \mathrm{kg}^{-1}\right)$} \\
\hline \multicolumn{2}{|l|}{ - Clay } & 15.6 & & $-\mathrm{N}$ & 49.0 \\
\hline \multicolumn{2}{|l|}{ - Silt } & 5.30 & Macro & $-P$ & 4.12 \\
\hline \multicolumn{2}{|l|}{ - Sand } & 79.1 & & $-\mathrm{K}$ & 199 \\
\hline \multicolumn{2}{|c|}{ Texture class } & Sandy loam & & $-\mathrm{Fe}$ & 2.96 \\
\hline \multicolumn{2}{|c|}{ Organic matter $\left(\mathrm{g} \mathrm{kg}^{-1}\right)$} & 6.71 & Micro & $-\mathrm{Mn}$ & 2.35 \\
\hline \multicolumn{2}{|c|}{$\mathrm{CaCO}_{3}\left(\mathrm{~g} \mathrm{~kg}^{-1}\right)$} & 78.3 & & $-\mathrm{Zn}$ & 0.89 \\
\hline \multicolumn{2}{|c|}{$\mathrm{pH}$ (Soil suspension 1:2.5) } & 8.35 & - SAR & & 22.8 \\
\hline \multirow{2}{*}{\multicolumn{2}{|c|}{$\mathrm{EC}\left(\mathrm{dSm}^{-1}\right)$ at soil paste extract }} & 16.7 & - ESP & & 24.5 \\
\hline & & & - CEC (cmo & & 19.8 \\
\hline \multicolumn{6}{|c|}{ IISoluble ions $\left(\mathbf{m m o l}_{\underline{c}} \underline{\mathbf{L}}^{-1}\right)$} \\
\hline \multirow{4}{*}{ Cations } & $-\mathrm{Na}^{+}$ & 94.1 & \multirow{4}{*}{ Anions } & $-\mathrm{Cl}^{-}$ & 89.1 \\
\hline & $-\mathrm{K}^{+}$ & 8.30 & & $-\mathrm{HCO}_{3}$ & 19.7 \\
\hline & $-\mathrm{Ca}^{2+}$ & 28.2 & & $-\mathrm{SO}_{4}=$ & 58.3 \\
\hline & $-\mathrm{Mg}^{2+}$ & 36.4 & & & \\
\hline
\end{tabular}

II in soil paste . 
Urea $(46 \% \mathrm{~N})$ was applied as soil application at a rate of $100 \mathrm{~kg} \mathrm{~N}^{\mathrm{N}} \mathrm{fe}^{-1}$ in two equal splits, before the $1^{\text {st }}$ and the $2^{\text {nd }}$ irrigations. Phosphorus fertilizer was added to all plots before sowing at a rate of $15 \mathrm{~kg} \mathrm{P}$ fed $^{-1}$ as superphosphate $(6.8 \% \mathrm{P})$. Potassium sulphate $(40 \% \mathrm{~K})$ was applied as soil application at a rate of $40 \mathrm{~kg} \mathrm{~K}$ $\mathrm{fed}^{-1}$ in two equal splits, 30 and 45 days after sowing. The used treatments in this study were 1) control; 2) gypsum at rate of 4 Mega gram $\left.(\mathrm{Mg}) \mathrm{fed}^{-1},(\mathrm{G1}) ; 3\right)$ gypsum at rate of $8 \mathrm{Mg} \mathrm{fed}^{-1},(\mathrm{G} 2)$; 4) elemental sulphur at rate of $2 \mathrm{Mg} \mathrm{fed}^{-1}$ (ES) and 5) sulphuric acid, (SA) at a rate of $500 \mathrm{~L}$ sulfuric acid $(36 \%)$ in $1000 \mathrm{~L}$ water per fed. Gypsum requirements (GR) were calculated to reduce the initial ESP from 24.5 to $10 \%$ for 30 -cm soil matrix according to USDA (1954).

TABLE 2. Some chemical properties of the used irrigation water during wheat plant.

\begin{tabular}{lccccc}
\hline Properties & $\mathbf{2 0 1 2}$ & $\mathbf{2 0 1 3}$ & Properties & $\mathbf{2 0 1 2}$ & $\mathbf{2 0 1 3}$ \\
\hline $\mathrm{pH}$ & 7.93 & 7.89 & & Micronutrients $\left(\mathbf{m g ~ L}^{-\mathbf{1}}\right)$ \\
$\mathrm{EC}\left(\mathrm{dSm}^{-1}\right)$ & 1.30 & 1.26 & $\mathrm{Fe}$ & 0.95 & 0.88 \\
Macronutrients $\left(\mathrm{mg} \mathrm{L}^{-1}\right)$ & & & $\mathrm{Mn}$ & 1.34 & 1.39 \\
$\mathrm{~N}-\mathrm{NH}_{4}^{+}$ & 6.98 & 6.71 & $\mathrm{Zn}$ & 0.75 & 0.78 \\
$\mathrm{~N}-\mathrm{NO}_{3}^{-}$ & 17.8 & 18.8 & & & \\
$\mathrm{P}$ & 1.97 & 2.06 & & & \\
$\mathrm{~K}$ & 9.03 & 9.06 & & & \\
\hline
\end{tabular}

ES and SA were added in two equal splits, 60 and 30 days before planting and interrupted by leaching process and then followed by flipping and deep plowing of the sub-soil.

Plant samples were taken at 30, 45,70 and 140 days after sowing (DAS) corresponding to vegetative, tillering, booting and maturity stages, respectively. Total content of $\mathrm{N}, \mathrm{P}$ and $\mathrm{K}$ as well as $\mathrm{Fe}, \mathrm{Mn}$ and $\mathrm{Zn}$ in plant samples were measured.

At maturity, $2 \mathrm{~m}^{2}$ of each plot were harvested, plants were air dried and yields were recorded. In addition, representative ten plants were taken randomly from each plot and recorded the following characters: plant height $(\mathrm{cm})$, number of spikes plant ${ }^{-1}$, 1000-grains weight $(\mathrm{g})$, grains yield $\left(\mathrm{Mg} \mathrm{fed}^{-1}\right)$ and straw yield $\left(\mathrm{Mg} \mathrm{fed}^{-1}\right)$ were recorded. Grain protein content was obtained by multiplying grain $\mathrm{N}$ concentration by 6.25 . Protein yield $\left(\mathrm{kg} \mathrm{fed}^{-1}\right)=$ protein percentage $\mathrm{x}$ grain yield.

\section{Soil sampling}

After crop harvesting, three soil layer samples corresponding depths of $0-20$, $20-40$ and $40-60 \mathrm{~cm}$ from each treatment were collected separately. The samples were dried, ground to pass through $2 \mathrm{~mm}$ sieve, labeled and stored for 
analyses for some soil characteristics, i.e., $\mathrm{pH}, \mathrm{EC}$, available $\mathrm{N}, \mathrm{P}, \mathrm{K}, \mathrm{Fe}, \mathrm{Mn}$ and Zn.

Methods of analysis

The plant materials were oven dried at $70^{\circ} \mathrm{C}$ ground and kept for chemical analysis. $0.4 \mathrm{~g}$ was wet-digested using mixture of concentrated sulphuric and perchloric acids and different analysis were done according to Ryan et al. (1996). The analysis of soil and water were made using the methods described by Klute (1986) and Page (1982). Available and total phosphorus as well as Fe, Mn, and $\mathrm{Zn}$ were determined using Inductively Coupled Plasma (ICP) and spectrometry model 400 after Soltanpour (1985). Ammonium and nitrate of irrigation water were determined according to the method described by Markus et al. (1982).

Chlorophyll $\mathrm{a}$ and $\mathrm{b}$ were determined in fresh weight of leaf according to Saric et al. (1967). Total proline content was determined as by Bates et al. (1973).

\section{Statistical analysis}

Statistical analysis was assigned using MSTAT-C developed by Russel (1994).

\section{Results and Discussion}

\section{Soil properties after harvest}

Soil $\mathrm{pH}$ and $\mathrm{EC}\left(\mathrm{dS} \mathrm{m}^{-1}\right)$

The data representing effect of sulphur sources on soil EC and $\mathrm{pH}$ are presented in Table 3. Values in combined data of the two studied seasons show that, soil $\mathrm{pH}$ was slightly decreased and ranged between $8.35-7.92$ for control and SA treatments, respectively in $0-20 \mathrm{~cm}$ layer; $8.30-7.95$ for the same treatments but at $20-40 \mathrm{~cm}$ depth layer and $8.24-8.01$ at $40-60 \mathrm{~cm}$ layer. The range between the two treatments narrowed by depth. Application of gypsum at the rate of $4 \mathrm{Mg} \mathrm{fed}^{-1}$ and $8 \mathrm{Mg} \mathrm{fed}^{-1}$ slightly decreased soil $\mathrm{pH}$ as compared to that in the control plot. This trend was true for all soil layers $(0-20 \mathrm{~cm}),(20-40$ $\mathrm{cm})$ and $(40-60 \mathrm{~cm})$. However, the decrease in soil $\mathrm{pH}$ in these layers could be discussed as follows: calcium ions react with bicarbonate to precipitate calcite $\left(\mathrm{CaCO}_{3}\right)$ and release protons $\left(\mathrm{H}^{+}\right)$in soil solution which neutralize the hydroxide ions $\left(\mathrm{OH}^{-}\right)$and decrease the soil $\mathrm{pH}$ (Rasouli et al., 2013). Also, the decrease in soil $\mathrm{pH}$ due to gypsum application was probably due to combination of more than one factor, mainly the replacement of sodium by calcium and the formation of neutral salts with $\mathrm{SO}_{4}=$ and a decrease in sodium concentration as a fraction of the cations. Moreover, gypsum solubility is also enhanced as a result of increased ionic strength of solution and the formation of the sodium sulfate ion pair. Besides, large quantities of $\mathrm{CO}_{2}$ have been evolved during leaching process, some of which would become soluble in soil solution giving carbonic acids (Abdel-Fattah, 2012). These results are in a harmony with those obtained with Ahmed et al. (2006) and Sabir et al. (2007).

With respect to ES and $\mathrm{SA}$, the $\mathrm{pH}$ values were found to have decreased by 0.28 and $0.32 \mathrm{pH}$ units, respectively and SA treatment gave the lowest value 
(7.92) at $0-20 \mathrm{~cm}$ layer compared with the control. Poraas et al. (2009) indicated that the use of the acidic sulphur materials such as mineral sulphur had very negligible influence on reduce the $\mathrm{pH}$. Farook and Khan (2010) stated that, the use of sulfidic materials decreased soil $\mathrm{pH}$ by 0.1 to $0.2 \mathrm{pH}$ units compared with the initial soils.

TABLE 3. Soil pH, EC, available macro and micronutrients content in soil after harvest at different depth layers $(0-60 \mathrm{~cm})$.

\begin{tabular}{|c|c|c|c|c|c|c|c|c|c|c|}
\hline \multirow{3}{*}{\multicolumn{2}{|c|}{ 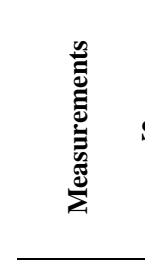 }} & \multirow{3}{*}{ Seasons } & Control & G1 & \multirow{2}{*}{ G2 } & \multicolumn{2}{|l|}{ ES } & \multicolumn{3}{|l|}{ SA } \\
\hline & & & 离 & 窇 & & & 氮 & & 这 & \\
\hline & & & $0-20-40-60$ & 0- $20-40-60$ & $0-20-40-60$ & $0-20$ & $-40-60$ & 0- 20 & -40 & -60 \\
\hline \multirow{3}{*}{\multicolumn{2}{|c|}{ pH $(1: 2.5)$}} & $1^{s t}$ & 8.318 .348 .19 & 8.058 .068 .04 & 8.158 .138 .09 & 8.01 & 8.028 .03 & 7.95 & 8.00 & 8.02 \\
\hline & & $2^{n d}$ & 8.398 .268 .29 & 8.028 .038 .01 & 7.897 .958 .01 & 7.98 & 7.998 .02 & 7.88 & 7.90 & 8.00 \\
\hline & & combined & 1 8.358.308.24 & 8.048 .058 .03 & 8.028 .048 .05 & 8.00 & 8.018 .03 & 7.92 & 7.95 & 8.01 \\
\hline \multirow{3}{*}{\multicolumn{2}{|c|}{$\begin{array}{c}\mathbf{E C} \\
\left(\mathbf{d S m}^{-1}\right)\end{array}$}} & $\mathbf{1}^{s t}$ & 13.412 .713 .9 & 8.638 .979 .14 & 7.867 .967 .68 & 7.56 & 7.638 .47 & 7.26 & 7.34 & 8.33 \\
\hline & & $2^{n d}$ & 12.413 .612 .9 & 7.158 .208 .94 & 7.607 .688 .08 & 7.33 & $7.86 \quad 8.28$ & 6.82 & 6.88 & 7.12 \\
\hline & & combined & 12.913 .113 .4 & 7.898 .599 .04 & 7.737 .827 .88 & 7.45 & 7.758 .38 & 7.04 & 7.11 & 7.73 \\
\hline \multirow{18}{*}{ 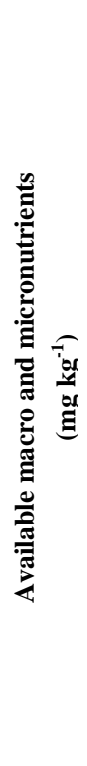 } & & $1^{s t}$ & 43.842 .141 .7 & 48.648 .646 .9 & 55.658 .643 .6 & 52.1 & 49.648 .7 & 58.2 & 56.9 & 51.3 \\
\hline & $\mathbf{N}$ & $2^{\text {nd }}$ & 41.442 .742 .3 & 2.548 .4 & 51.646 .257 .6 & 56.1 & 54.450 .8 & 61.3 & 58.8 & 53.5 \\
\hline & & combined & 142.642.442.0 & 51.950 .647 .7 & 53.652 .450 .6 & 54.1 & $\begin{array}{lll}52.0 & 49.8\end{array}$ & 59.8 & 57.9 & 52.4 \\
\hline & & $\mathbf{1}^{s t}$ & 3.723 .893 .79 & 4.924 .883 .55 & 5.764 .994 .56 & 4.98 & 4.963 .73 & 5.04 & 5.01 & 3.89 \\
\hline & $\mathbf{P}$ & $2^{n d}$ & 3.923 .613 .43 & 4.964 .923 .72 & 4.164 .634 .70 & 5.02 & 4.994 .02 & 5.09 & 5.05 & 3.91 \\
\hline & & combined & 3.823.753.61 & 4.944 .903 .64 & 4.964 .814 .63 & 5.00 & 4.983 .88 & 5.07 & 5.03 & 3.91 \\
\hline & & $\mathbf{1}^{s t}$ & 206181189 & $\begin{array}{lll}198 & 195 & 185\end{array}$ & $\begin{array}{lll}214 & 199 & 198\end{array}$ & 203 & $198 \quad 194$ & 207 & 203 & 197 \\
\hline & $\mathbf{K}$ & $2^{n d}$ & 192193173 & 203201188 & $\begin{array}{lll}192 & 193 & 186\end{array}$ & 209 & 206197 & 213 & 208 & 201 \\
\hline & & combined & 199187181 & $\begin{array}{lll}201 & 198 & 187\end{array}$ & $\begin{array}{lll}203 & 196 & 192\end{array}$ & 206 & 202196 & 210 & 206 & 199 \\
\hline & & $1^{\text {st }}$ & 2.811 .961 .63 & 2.792 .832 .72 & 2.762 .892 .64 & 2.88 & 2.842 .77 & 2.98 & 2.94 & 2.88 \\
\hline & $\mathbf{F e}$ & $2^{n d}$ & 3.111 .701 .99 & 2.822 .862 .74 & 2.962 .772 .78 & 2.93 & 2.942 .85 & 3.04 & 3.00 & 2.90 \\
\hline & & combined & 2.961.831.81 & 2.812 .852 .73 & 2.862 .832 .71 & 2.91 & 2.892 .81 & 3.01 & 2.97 & 2.89 \\
\hline & & $1^{\text {st }}$ & 1.951 .991 .86 & 2.111 .861 .97 & 2.012 .051 .98 & 2.12 & 2.072 .00 & 2.31 & 2.46 & 2.29 \\
\hline & Mn & $2^{n d}$ & 1.982 .031 .91 & 1.932 .001 .73 & $2.07 \quad 2.052 .01$ & 2.15 & 2.102 .04 & 2.39 & 2.12 & 2.13 \\
\hline & & combined & 1.972.011.89 & 2.021 .931 .85 & 2.042 .052 .00 & 2.14 & 2.092 .02 & 2.35 & 2.29 & 2.21 \\
\hline & & $\mathbf{1}^{s t}$ & 0.780 .790 .71 & 0.930 .810 .73 & 0.890 .820 .76 & 0.93 & $\begin{array}{lll}0.81 & 0.73\end{array}$ & 0.88 & 0.84 & 0.79 \\
\hline & $\mathbf{Z n}$ & $2^{n d}$ & 0.810 .830 .74 & 0.850 .830 .79 & 0.920 .840 .80 & 0.85 & 0.910 .89 & 0.97 & 0.90 & 0.88 \\
\hline & & combin & 10.800 .810 .73 & 0.890 .820 .76 & 0.910 .830 .78 & 0.89 & $\begin{array}{lll}0.86 & 0.81 \\
\end{array}$ & 0.93 & 0.87 & 0.8 \\
\hline
\end{tabular}

As for soil salinity, data in Table 3 declare a noticeable decrease in soil salinity as a result of treating soil with different treatments for all soil layers $0-20 \mathrm{~cm}, 20-40 \mathrm{~cm}$ and $40-60 \mathrm{~cm}$ in compare with the control. The effect is more pronounced due to the sulphuric acid treatment and the EC value $7.53 \mathrm{dS} \mathrm{m}^{-1}$ was recorded compared with

Egypt. J. Soil Sci. 53, No. 2 (2013) 
EC value of control $\left(13.2 \mathrm{dS} \mathrm{m}^{-1}\right)$ and gave $43 \%$ rate of depression than the control.

Regarding the effect of the treatments it's followed the order; $\mathrm{SA}>\mathrm{ES}>\mathrm{G} 2>$ $\mathrm{G} 1>$ Control for both $\mathrm{pH}$ and EC. In addition, sulphuric acid was capable to mobilize base cations from the soil. The $\mathrm{H}^{+}$ion in the acidic water displaces the cations from the exchange sites, reduces the exchangeable cations and increases the concentrations of these cations in the soil solution. Similar results were obtained by Mahmood et al. (2013).

\section{Residual available N, $P$ and $K$ macronutrients}

Table 3 reveals that the application of different sulphur sources increased the concentration of available nitrogen, phosphorus and potassium in the soil compared with the control for all soil layers under study. In this regard, El-Kouny (2009) pointed out that application of elemental sulphur increased total $\mathrm{N}$ and availability of $\mathrm{P}$ and $\mathrm{K}$ in soil sample as compared with the control. The plots under sulphuric acid treatment showed the maximum accumulation of available N, P and $\mathrm{K}$. Highest soil available $\mathrm{N}$ and $\mathrm{K}$ contents for combined data (55.1 and $202 \mathrm{mg} \mathrm{kg}^{-1}$ ), respectively were obtained due to sulphuric acid treatment while, it was $4.75 \mathrm{mg}$ $\mathrm{kg}^{-1}$ for available $\mathrm{P}$ due to $\mathrm{G} 2$ treatment.

\section{Residual available Fe, Mn and Zn micronutrients}

The concentration of available Fe, Mn and $\mathrm{Zn}$ followed the same trend of that observed for macronutrients hence, application of SA, ES, G1 and G2 treatments were increased the concentration of available $\mathrm{Fe}, \mathrm{Mn}$ and $\mathrm{Zn}$ in the soil compared with the control. In this regard, Khan et al. (2007) reported that application of sulfidic materials was effective in enhancing the release of essential plant nutrients into the growing media, which are very essential for crop production in poor soils. The highest soil available $\mathrm{Fe}, \mathrm{Mn}$ and $\mathrm{Zn}$ contents for combined data $\left(2.92,2.41\right.$ and $\left.0.85 \mathrm{mg} \mathrm{kg}^{-1}\right)$, respectively were obtained due to sulphuric acid treatment.

Regarding to soil profile depths, the differences among those depths were slightly. They were in gradual decreases in their content by depth. That observation could be attributed to sulphur in different sources added to plough layer moved slowly downward depth in addition to plant consumption where no pronounced quantities of these nutrients were in excess to flow down profile depth.

\section{Yield and its attributes}

Growth characters

Some growth characters of wheat plants are shown in Table 4. Gypsum, elemental sulphur and sulphuric acid treatments significantly increased 1000-grains weight, plant height and number of spikes plant ${ }^{-1}$ as compared to the control treatments. These increases may be due to calcium, while it is an essential for plant cell wall structure, provides normal transport and retention of other elements as well as strength in the plant. Among the treatments, SA was found to be the best source of 
S followed by ES, G2 and then G1 because of its high concentrations its influence on reducing soil $\mathrm{pH}$, improving soil structure and increasing the availability of certain plant nutrients. Data also indicated that application of sulphuric acid gave the highest values and increased the plant height, number of spikes plant ${ }^{-1}$ and 1000-grains weight by about $(36.8,78.9$ and $82.6 \%$ ) compared with untreated plants. Ali et al. (2012) reported that S application significantly enhanced wheat growth and yield. Tillering, plant height, spike length, number of grain spike-1, 1000-grain weight, straw and grain were statistically significant. This was the most probably due to increased $\mathrm{Ca}$ and $\mathrm{K}$ and decreased $\mathrm{Na}$ contents resulting in healthy environment for plant growth. These results are in harmony with those obtained by Ali et al. (2008) and Mazhar et al. (2011).

TABLE 4. Yield and yield attributes of wheat as affected by sulphur applications.

\begin{tabular}{|c|c|c|c|c|c|c|c|c|c|c|}
\hline & \multirow{2}{*}{ 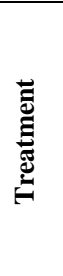 } & \multirow[b]{2}{*}{$\begin{array}{l}\tilde{0} \\
\text { हूँ } \\
\text { क }\end{array}$} & \multirow[b]{2}{*}{ 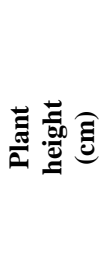 } & \multirow{2}{*}{ 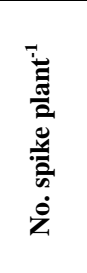 } & \multirow{2}{*}{ 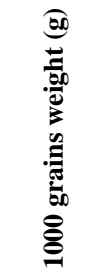 } & \multicolumn{3}{|c|}{ Yield $\left(\mathrm{Mg} \mathrm{fed}^{-1}\right)$} & \multirow{2}{*}{ 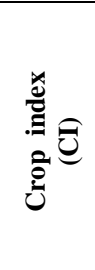 } & \multirow{2}{*}{ 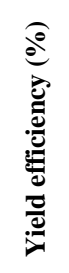 } \\
\hline & & & & & & 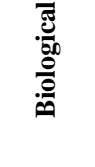 & 苞 & $\stackrel{5}{5}$ & & \\
\hline \multirow{3}{*}{\multicolumn{2}{|c|}{ Control }} & 2012 & 69.9 & 5.46 & 31.5 & 2.15 & 0.93 & 1.22 & 0.76 & 43.3 \\
\hline & & 2013 & 71.3 & 4.69 & 30.2 & 2.66 & 0.87 & 1.79 & 0.49 & 32.7 \\
\hline & & Combined & $70.6 \mathrm{e}$ & $5.08 \mathrm{~b}$ & $30.89 \mathrm{~d}$ & $2.41 \mathrm{~b}$ & $0.90 \mathrm{~b}$ & $1.51 \mathrm{c}$ & 0.62 & 38.0 \\
\hline \multirow{9}{*}{ 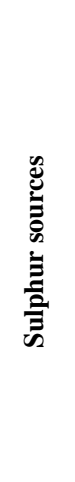 } & \multirow{2}{*}{ G1 } & $\begin{array}{l}2012 \\
2013\end{array}$ & $\begin{array}{l}84.6 \\
86.0\end{array}$ & $\begin{array}{l}7.69 \\
8.14\end{array}$ & $\begin{array}{l}45.7 \\
48.3\end{array}$ & $\begin{array}{l}3.14 \\
3.31\end{array}$ & $\begin{array}{l}1.29 \\
1.35\end{array}$ & $\begin{array}{l}1.85 \\
1.96\end{array}$ & $\begin{array}{l}0.70 \\
0.69\end{array}$ & $\begin{array}{l}41.1 \\
40.8\end{array}$ \\
\hline & & Combined & $85.3 \mathrm{~d}$ & $7.92 \mathrm{a}$ & $47.0 \mathrm{c}$ & $3.23 \mathrm{a}$ & $1.32 \mathrm{a}$ & $1.91 \mathrm{~b}$ & 0.69 & 40.9 \\
\hline & \multirow{3}{*}{ G2 } & 2012 & 88.7 & 8.88 & 51.6 & 3.42 & 1.39 & 2.05 & 0.68 & 40.6 \\
\hline & & 2013 & 87.0 & 9.05 & 53.1 & 3.52 & 1.37 & 2.15 & 0.64 & 40.9 \\
\hline & & Combined & $87.8 \mathrm{c}$ & $8.97 \mathrm{a}$ & $52.4 \mathrm{~b}$ & $3.47 \mathrm{a}$ & $1.38 \mathrm{a}$ & $2.10 \mathrm{ab}$ & 0.66 & 40.8 \\
\hline & \multirow{2}{*}{ ES } & $\begin{array}{l}2012 \\
2013\end{array}$ & $\begin{array}{l}89.0 \\
93.5\end{array}$ & $\begin{array}{l}8.87 \\
9.14\end{array}$ & $\begin{array}{l}52.1 \\
54.5\end{array}$ & $\begin{array}{l}3.50 \\
3.60\end{array}$ & $\begin{array}{l}1.36 \\
1.42\end{array}$ & $\begin{array}{l}2.14 \\
2.18\end{array}$ & $\begin{array}{l}0.64 \\
0.65\end{array}$ & $\begin{array}{l}38.9 \\
39.4\end{array}$ \\
\hline & & Combined & $91.2 \mathrm{~b}$ & $9.06 \mathrm{a}$ & $53.3 \mathrm{~b}$ & $3.55 \mathrm{a}$ & $1.39 \mathrm{a}$ & $2.16 \mathrm{ab}$ & 0.64 & 39.2 \\
\hline & \multirow{2}{*}{ SA } & $\begin{array}{l}2012 \\
2013\end{array}$ & $\begin{array}{l}95.8 \\
97.3\end{array}$ & $\begin{array}{l}8.95 \\
9.23\end{array}$ & $\begin{array}{l}55.1 \\
57.7\end{array}$ & $\begin{array}{l}3.61 \\
3.75\end{array}$ & $\begin{array}{l}1.37 \\
1.47\end{array}$ & $\begin{array}{l}2.24 \\
2.28\end{array}$ & $\begin{array}{l}0.61 \\
0.65\end{array}$ & $\begin{array}{l}38.0 \\
39.2\end{array}$ \\
\hline & & Combined & $96.5 \mathrm{a}$ & $9.09 \mathrm{a}$ & 56.4 a & $3.68 \mathrm{a}$ & $1.42 \mathrm{a}$ & $2.26 \mathrm{a}$ & 0.63 & 38.6 \\
\hline
\end{tabular}

\begin{tabular}{lllllllll}
\hline LSD at 0.05 (Combined) & 1.29 & 2.01 & 1.18 & $\mathbf{0 . 5 8}$ & $\mathbf{0 . 3 0}$ & $\mathbf{0 . 3 5}$ & ns & ns
\end{tabular}

G1: gypsum rate $4 \mathrm{Mg} \mathrm{fed}^{-1}$. G2: gypsum rate $8 \mathrm{Mg} \mathrm{fed}^{-1}$. ES: elemental Sulphur. SA: sulphuric acid. The values followed by a different letters are significantly different at $p \leq 0.05$. Ns: not significant. Crop index (CI): (seed/straw) ratio; Yield efficiency (YE): yield of grains / (yield of straw + grains) $x$ 100 ,

Straw and grain yields

Data presented in Table 4 show that grains and straw yield were significantly increased due to the addition of gypsum, elemental sulphur and sulphuric acid compared to the control treatment. These increases might be attributed to the role of calcium, which is essential for plant as previously mentioned. Also, calcium is

Egypt. J. Soil Sci. 53, No. 2 (2013) 
essential for many plant functions, some of them are proper cell division and elongation, enzyme activity and metabolism. These results are well supported by the findings of Sabir et al. (2007) and Farook \& Khan (2010).

The maximum straw and grain yields (2.26 and $1.42 \mathrm{Mg} \mathrm{fed}^{-1}$, respectively) were produced by the treatment of sulphuric acid. It was followed by elemental sulphur, G2 and then G1 treatments. The increase percentage over the control for SA, ES, G2 and G1 treatments were 57.8, 54.4, 53.3 and $46.7 \%$ for grains as well as 49.7, 43.0, 39.0 and $26.5 \%$ for straw, respectively. The data presents the following descending order; SA > ES > G2 > G1> control. These results are similar to that obtained by Ghaudhry (2001), who concluded that gypsum application to rice and wheat crops at $75 \%$ G.R. enhanced the paddy and grain yield by 18 and 17\%, respectively. In this regard, Farook and Khan (2010) pointed out that the application of sulphidic material increased the grain yield of rice plant by $108 \%$ over the control for Sirajgonj soil and 135\% for Gazipur soil irrespective of application rates. In case of gypsum, these increments were 35\% and 58\% for Sirajgonj soil and Gazipur soil, respectively. Tan et al. (2000) found that all sulphur sources (ammonium sulphate, elemental sulphur and gypsum) had a positive effect on rice yield from 9 to 10 percent higher than plots receiving no $\mathrm{S}$ showing that application of sulphuric acid resulted in higher yield and promoted rapid amelioration of saline-sodic soils. These results are in agreement with Sadiq et al. (2007) and Jena \& Kabi (2012).

\section{Yield efficiency (\%) and Crop index (CI)}

From data in Table 4, it can be observed that application of gypsum and sulphur treatments insignificantly increased yield efficiency and crop index of wheat plants. The values were $7.76 \%, 7.31 \%, 3.05 \%$ and $1.58 \%$ for the yield efficiency and $11.1 \%, 5.45 \%, 3.21 \%$ and $0.80 \%$ for crop index due to the treatments, respectively in the following descending order: G1 > G2 > ES > SA of the control. Similarly, harvest index showed the same trend of yield efficiency. Farook and Khan (2010) pointed out that the application of sulphidic material exerted significant effects in increasing the harvest index of rice, but the application of gypsum was not always significant. In addition, Haq et al. (2007) indicated that gypsum at full rate of $100 \%$ gypsum requirements significantly increased harvest index of wheat as compared to control.

\section{Macro and micronutrients content at different growth stages}

Data presented in Fig.1 illustrated that the application of gypsum and sulphur as elemental sulphur or sulphuric acid increased the concentrations of N, P, K, $\mathrm{Fe}, \mathrm{Mn}$ and $\mathrm{Zn}$ in wheat plants compared to the control. This was true at all growth stages. Mazhar et al. (2011) stated that sulphur improves the use efficiency of the essential plant nutrients; particularly nitrogen and phosphorus. Also, application of gypsum showed more pronounced effects on the nutrients percentage in all plant organs than sulphur treatments. This effect seemed to be dependent on soil properties that limit the buffering capacity and native nutrient content. 
Plant requirements of sulphur are equal to or exceed those for phosphorus. It is one of major nutrients essential for plant growth and plant protection mechanisms. Sulphur application enhanced the uptake of N, P, K and Zn by the plant. Due to its synergistic effect, the efficiency of these elements is enhanced which results in increased crop productivity. Application of $S$ is useful not only for increasing crop production and quality of the produce but also improves soil conditions for healthy crop (Zhao, 1999). These results are in agreement with those obtained by Badr et al. (2002) and Farook \& Khan (2010).
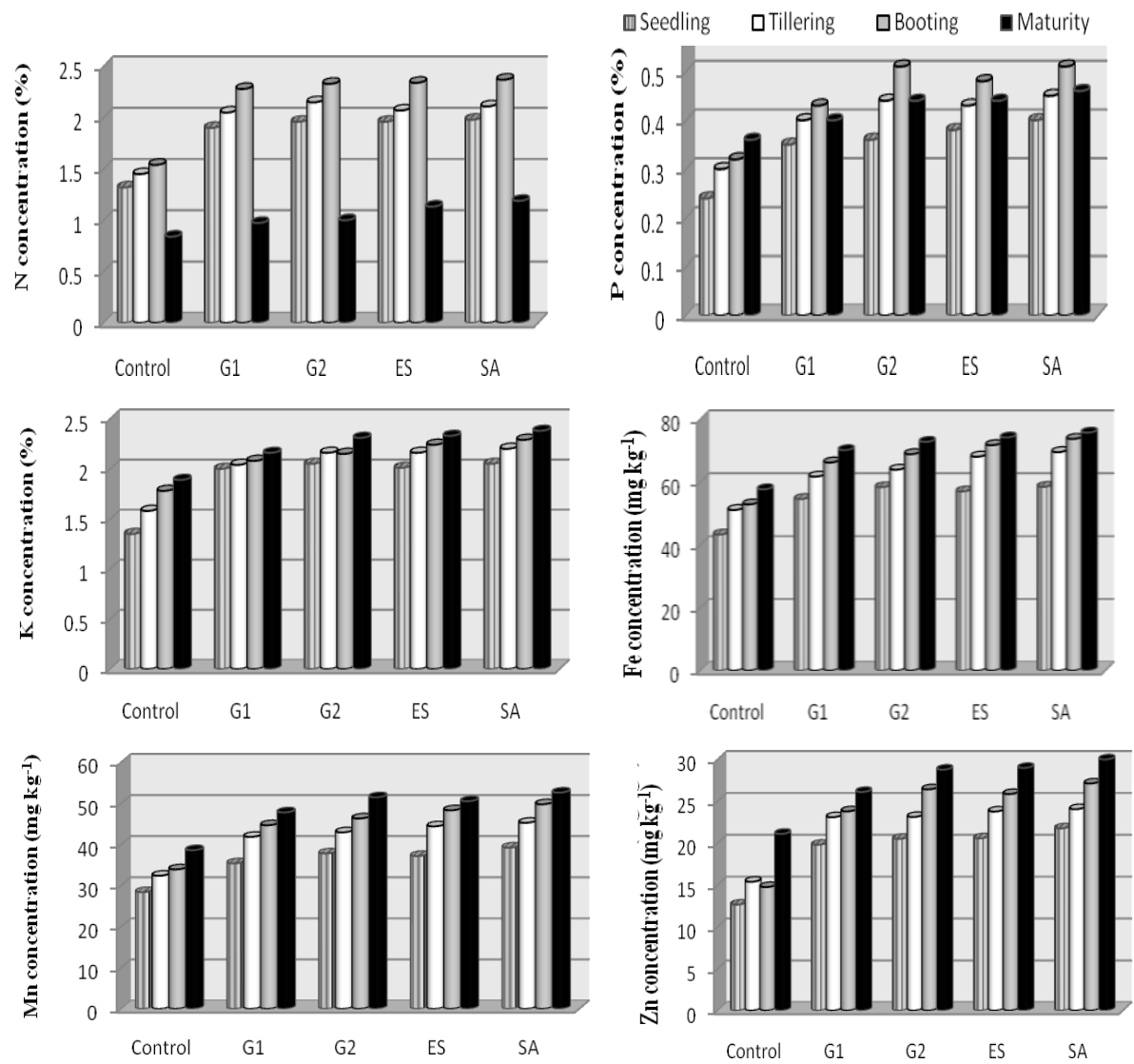

Fig. 1. N, P and $\mathrm{K}$ content $(\%)$ as well as $\mathrm{Fe}, \mathrm{Mn}$ and $\mathrm{Zn}$ content $\left(\mathrm{mg} \mathrm{kg}^{-1}\right)$ of wheat during different growth stages (seedling, booting, tillering and straw at maturity) as affected by different sulphur sources.

G1: gypsum rate, $4 \mathrm{Mg}$ fed $^{-1}$; G2: gypsum rate, $8 \mathrm{Mg}$ fed $^{-1}$; ES: elemental sulphur; SA: sulphuric acid.

\section{Macronutrients content}

Data in Table 5 show that $\mathrm{N}, \mathrm{P}$ and $\mathrm{K}$ uptake were increased significantly due to addition of all treatments. Sulphuric acid treatment was superior for increasing the uptake of $\mathrm{N}, \mathrm{P}$ and $\mathrm{K}$ as compared to the other treatments. This promoting effect

Egypt. J. Soil Sci. 53, No. 2 (2013) 
could be related to the supplementary effect of gypsum and sulphur on reducing soil $\mathrm{pH}$, improving soil structure and increasing the availability of nutrients in soil and also, improves the use efficiency of other essential plant nutrients, particularly nitrogen and phosphorus (Mazhar et al., 2011). These results are in a harmony with those obtained by Ali et al. (2008) and Haq et al. (2007).

Statistical analysis shows that sulphuric acid treatment was superior for increasing the uptake of N, P and K to the other treatments. The positive effect was in the ascending order of $\mathrm{SA}>\mathrm{ES}>\mathrm{G} 2>\mathrm{G} 1>$ control for all nutrients under study either for straw or grains. The applications showed insignificant differences among them for $\mathrm{N}$ and $\mathrm{P}$ uptake while, $\mathrm{SA}$ was significant than gypsum for K uptake.

Highest N, P and k-uptake of straw 26.9, 10.3 and $54.4 \mathrm{~kg} \mathrm{fed}^{-1}$, respectively as well as $33.1,8.95$ and $23.8 \mathrm{~kg} \mathrm{fed}^{-1}$, respectively for grains were obtained due to the sulphuric acid treatment.

TABLE 5. Macronutrients uptake $\left(\mathrm{kg} \mathrm{fed}^{-1}\right)$ in wheat plants as affected by sulphur applications.

\begin{tabular}{|c|c|c|c|c|c|c|c|c|}
\hline \multirow{3}{*}{\multicolumn{2}{|c|}{ Treatment }} & \multirow{3}{*}{ Season } & \multicolumn{6}{|c|}{ Macronutrients $\left(\mathrm{kg} \mathrm{fed}^{-1}\right)$} \\
\hline & & & \multicolumn{3}{|c|}{ Straw } & \multicolumn{3}{|c|}{ Grains } \\
\hline & & & $\mathbf{N}$ & $\mathbf{P}$ & $\mathbf{K}$ & $\mathbf{N}$ & $\mathbf{P}$ & $\mathbf{K}$ \\
\hline \multirow{3}{*}{\multicolumn{2}{|c|}{ Control }} & 2012 & 10.7 & 4.76 & 24.8 & 12.9 & 3.35 & 9.86 \\
\hline & & 2013 & 14.7 & 5.65 & 33.0 & 12.6 & 3.65 & 10.4 \\
\hline & & Combined & $12.7 \mathrm{~b}$ & $5.21 \mathrm{~b}$ & $28.9 \mathrm{c}$ & $12.8 \mathrm{~b}$ & $3.50 \mathrm{~b}$ & $10.1 \mathrm{~b}$ \\
\hline \multirow{8}{*}{ 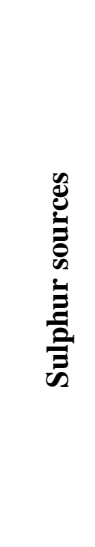 } & \multirow{2}{*}{ G1 } & $\begin{array}{l}2012 \\
2013\end{array}$ & $\begin{array}{l}17.9 \\
19.3\end{array}$ & $\begin{array}{l}7.92 \\
7.22\end{array}$ & $\begin{array}{l}39.9 \\
43.3\end{array}$ & $\begin{array}{l}27.6 \\
29.3\end{array}$ & $\begin{array}{l}6.58 \\
7.16\end{array}$ & $\begin{array}{l}19.1 \\
20.9\end{array}$ \\
\hline & & Combined & $18.6 \mathrm{a}$ & $7.57 \mathrm{ab}$ & $41.6 \mathrm{~b}$ & $28.5 \mathrm{a}$ & $6.87 \mathrm{ab}$ & $20.0 \mathrm{a}$ \\
\hline & \multirow{2}{*}{ G2 } & $\begin{array}{l}2012 \\
2013\end{array}$ & $\begin{array}{l}20.3 \\
21.7\end{array}$ & $\begin{array}{l}10.1 \\
9.50\end{array}$ & $\begin{array}{l}48.1 \\
51.9\end{array}$ & $\begin{array}{l}30.6 \\
30.8\end{array}$ & $\begin{array}{l}8.20 \\
7.12\end{array}$ & $\begin{array}{l}22.0 \\
22.7\end{array}$ \\
\hline & & Combined & 21.0 a & $9.79 \mathrm{a}$ & 50.0 ab & 30.7 a & $7.66 \mathrm{a}$ & $22.4 \mathrm{a}$ \\
\hline & \multirow{2}{*}{ ES } & $\begin{array}{l}2012 \\
2013\end{array}$ & $\begin{array}{l}24.0 \\
24.9\end{array}$ & $\begin{array}{l}10.0 \\
8.93\end{array}$ & $\begin{array}{l}50.2 \\
52.4\end{array}$ & $\begin{array}{l}30.3 \\
32.1\end{array}$ & $\begin{array}{l}7.75 \\
8.24\end{array}$ & $\begin{array}{l}22.2 \\
23.7\end{array}$ \\
\hline & & Combined & $24.5 \mathrm{a}$ & $9.46 \mathrm{a}$ & $51.3 \mathrm{ab}$ & $31.2 \mathrm{a}$ & $7.99 \mathrm{a}$ & $23.0 \mathrm{a}$ \\
\hline & \multirow{2}{*}{ SA } & $\begin{array}{l}2012 \\
2013\end{array}$ & $\begin{array}{l}26.4 \\
27.4\end{array}$ & $\begin{array}{l}10.7 \\
9.98\end{array}$ & $\begin{array}{l}54.4 \\
54.5\end{array}$ & $\begin{array}{l}31.6 \\
34.5\end{array}$ & $\begin{array}{l}8.49 \\
9.41\end{array}$ & $\begin{array}{l}22.7 \\
24.8\end{array}$ \\
\hline & & Combined & 26.9 a & $10.3 \mathrm{a}$ & $54.4 \mathrm{a}$ & 33.1 a & $8.95 \mathrm{a}$ & $23.8 \mathrm{a}$ \\
\hline \multicolumn{3}{|c|}{ LSD at 0.05 (Combined) } & 7.42 & 3.12 & 12.0 & 8.15 & 3.52 & 6.89 \\
\hline
\end{tabular}

See footnotes of Table 4.

Micronutrients content

As shown in Table 6, Fe, Mn and $\mathrm{Zn}$ uptake followed the same trend of that for N, P and K uptake. Hence, the addition of all treatment significantly increased 
$\mathrm{Fe}, \mathrm{Mn}$ and $\mathrm{Zn}$ uptake compared to the control. Sulphuric acid treatment was most effective for increasing the uptake of Fe, $\mathrm{Mn}$ and $\mathrm{Zn}$ as compared to the other treatments. The responses percentage to $\mathrm{Fe}, \mathrm{Mn}$ and $\mathrm{Zn}$ uptake by wheat straw over control was 102, 106 and $112 \%$, and for grains 108, 147 and $254 \%$, respectively. Jena and Kabi (2012) stated that sulphur application increased $\mathrm{Fe}, \mathrm{Mn}, \mathrm{Zn}$ and $\mathrm{Cu}$ uptake by rice plants. Also, significant improvement is usually expected in the use of gypsum on saline soils as sources of Ca and S. Bello (2012) found that the improvement in yield and nutrient content is due to the displacement of sodium by calcium and increase in nutrient use efficiency of rice crop. Sulphur fertilization enhanced the uptake of $\mathrm{N}, \mathrm{P}, \mathrm{K}$ and $\mathrm{Zn}$ in the plant. Due to its synergistic effect, the efficiency of these elements is enhanced which results in increased crop productivity. Application of S fertilizer is useful not only for increasing crop production and quality of the produce but also improves soil conditions for healthy crop. These results are in a harmony with those obtained by Badr et al. (2002).

TABLE 6. Micronutrients uptake $\left(\mathrm{kg} \mathrm{fed}^{-1}\right)$ in wheat plants as affected by sulphur applications during the two growing seasons of 2011/2012 \& 2012/2013 and their combined analysis .

\begin{tabular}{|c|c|c|c|c|c|c|c|c|}
\hline \multirow{3}{*}{\multicolumn{2}{|c|}{ Treatment }} & \multirow{3}{*}{ Season } & \multicolumn{6}{|c|}{ Micronutrients $\left(\mathrm{g}\right.$ fed. $\left.{ }^{-1}\right)$} \\
\hline & & & \multicolumn{3}{|c|}{ Straw } & \multicolumn{3}{|c|}{ Grains } \\
\hline & & & $\mathbf{F e}$ & Mn & Zn & $\mathbf{F e}$ & Mn & Zn \\
\hline \multirow{3}{*}{\multicolumn{2}{|c|}{ Control }} & 2012 & 103 & 48.3 & 24.2 & 54.4 & 30.8 & 10.9 \\
\hline & & 2013 & 158 & 67.4 & 40.0 & 49.6 & 30.7 & 15.2 \\
\hline & & Combined & $131 \mathrm{c}$ & $57.8 \mathrm{c}$ & $32.1 \mathrm{c}$ & $52.0 \mathrm{~b}$ & $30.8 \mathrm{~b}$ & $13.1 \mathrm{~d}$ \\
\hline \multirow{8}{*}{ 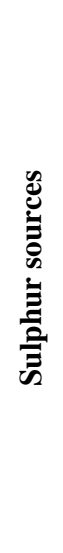 } & \multirow{2}{*}{ G1 } & $\begin{array}{l}2012 \\
2013\end{array}$ & $\begin{array}{l}179 \\
206\end{array}$ & $\begin{array}{l}87.2 \\
95.1\end{array}$ & $\begin{array}{l}48.7 \\
50.7\end{array}$ & $\begin{array}{l}92.2 \\
92.9\end{array}$ & $\begin{array}{l}48.4 \\
53.2\end{array}$ & $\begin{array}{l}33.5 \\
29.7\end{array}$ \\
\hline & & Combined & $193 \mathrm{~b}$ & $91.1 \mathrm{~b}$ & $49.7 \mathrm{~b}$ & $92.6 \mathrm{a}$ & 50.8 a & $31.6 \mathrm{c}$ \\
\hline & \multirow{2}{*}{ G2 } & $\begin{array}{l}2012 \\
2013\end{array}$ & $\begin{array}{l}219 \\
220\end{array}$ & $\begin{array}{l}107 \\
108\end{array}$ & $\begin{array}{l}61.2 \\
59.5\end{array}$ & $\begin{array}{c}103 \\
98.1\end{array}$ & $\begin{array}{l}59.2 \\
60.7\end{array}$ & $\begin{array}{l}36.4 \\
37.8\end{array}$ \\
\hline & & Combined & $220 \mathrm{ab}$ & 108ab & $60.4 \mathrm{a}$ & $100 \mathrm{a}$ & $60.0 \mathrm{a}$ & $37.1 \mathrm{bc}$ \\
\hline & \multirow{2}{*}{ ES } & $\begin{array}{l}2012 \\
2013\end{array}$ & $\begin{array}{l}242 \\
238\end{array}$ & $\begin{array}{l}106 \\
112\end{array}$ & $\begin{array}{l}61.9 \\
63.2\end{array}$ & $\begin{array}{l}102 \\
104\end{array}$ & $\begin{array}{l}63.5 \\
71.1\end{array}$ & $\begin{array}{l}38.8 \\
43.9\end{array}$ \\
\hline & & Combined & $240 \mathrm{ab}$ & $109 \mathbf{a b}$ & $62.6 \mathrm{a}$ & $103 \mathrm{a}$ & $67.3 \mathrm{a}$ & $41.3 \mathrm{ab}$ \\
\hline & \multirow{2}{*}{ SA } & $\begin{array}{l}2012 \\
2013\end{array}$ & $\begin{array}{l}258 \\
269\end{array}$ & $\begin{array}{l}119 \\
120\end{array}$ & $\begin{array}{l}66.0 \\
69.7\end{array}$ & $\begin{array}{l}102 \\
113\end{array}$ & $\begin{array}{l}70.7 \\
81.3\end{array}$ & $\begin{array}{l}44.4 \\
48.4\end{array}$ \\
\hline & & Combined & 264 a & $119 a$ & $67.9 \mathrm{a}$ & $108 \mathrm{a}$ & $76.0 \mathrm{a}$ & $46.4 \mathrm{a}$ \\
\hline \multicolumn{3}{|c|}{ LSD at 0.05 (Combined) } & 38.8 & 19.8 & 10.8 & 33.1 & 11.7 & 9.09 \\
\hline
\end{tabular}

See footnotes of Table 4 .

Egypt. J. Soil Sci. 53, No. 2 (2013) 


\section{Total chlorophyll and proline content}

It is clear from Table 7 that the content of chlorophyll $(a+b)$ was significantly increased by the addition of treatments SA, ES, G2 and G1 compared to the control while, the differences among the applications were insignificant. The highest chlorophyll content $2.66 \mathrm{mg} \mathrm{g}^{-1}$ fresh weight of leaves was obtained due to the application of sulphuric acid representing an increase of $49.4 \%$ over the control.

As for proline content in fresh weight of leaves, obtained data revealed that there were significant differences between gypsum rates compared to control and the other sulphur sources, without significant differences among them. Mazhar et al. (2011) pointed out that proline content decreased by using gypsum or sulphur in the leaves, stem and roots of (Schefflera arboricola). Also, there is evidence that proline accumulation is a sign of injury rather that of resistance. Pratiksha et al. (2010) reported that proline content increased as the external supply of calcium to saline soil increased. According to Table 7 the increases followed the order: G1 > G2 > $\mathrm{ES}>$ control $>\mathrm{SA}$.

TABLE 7. Protein content (\%) and protein yield $\left(\mathrm{kg} \mathrm{fed}^{-1}\right)$ of wheat grains as well as chlorophyll $\mathrm{a}+\mathrm{b}\left(\mathrm{mg} \mathrm{g}^{-1}\right.$ fresh weight of leaves) and proline content ( $\mu \mathrm{molg}^{-1}$ fresh weight of leaves) as affected by sulphur applications.

\begin{tabular}{|c|c|c|c|c|c|c|}
\hline \multicolumn{2}{|r|}{ Treatment } & Season & 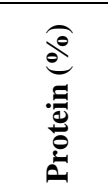 & 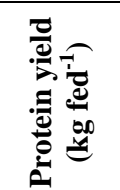 & 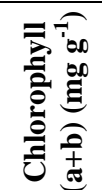 & 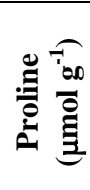 \\
\hline \multirow{3}{*}{\multicolumn{2}{|c|}{ Control }} & 2012 & 8.69 & 80.8 & 1.67 & 13.6 \\
\hline & & 2013 & 9.06 & 78.8 & 1.89 & 12.1 \\
\hline & & Combined & $8.88 \mathrm{c}$ & $79.8 \mathrm{~b}$ & $1.78 \mathrm{~b}$ & $12.9 \mathrm{c}$ \\
\hline \multirow{11}{*}{ 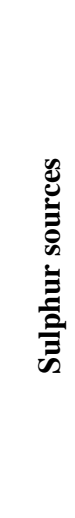 } & \multirow{3}{*}{ G1 } & 2012 & 13.4 & 172.9 & 2.55 & 19.0 \\
\hline & & 2013 & 13.6 & 183.6 & 2.58 & 17.7 \\
\hline & & Combined & $13.5 \mathrm{~b}$ & $178.3 \mathrm{a}$ & $2.57 \mathrm{a}$ & $18.4 \mathrm{a}$ \\
\hline & \multirow{3}{*}{ G2 } & 2012 & 13.8 & 191.8 & 2.63 & 16.2 \\
\hline & & 2013 & 14.1 & 193.2 & 2.53 & 14.6 \\
\hline & & Combined & $13.9 \mathrm{ab}$ & 191.8 a & $2.58 \mathrm{a}$ & $15.4 \mathrm{~b}$ \\
\hline & \multirow{3}{*}{ ES } & 2012 & 13.9 & 189.0 & 2.63 & 14.5 \\
\hline & & 2013 & 14.1 & 200.2 & 2.59 & 12.0 \\
\hline & & Combined & $14.1 \mathrm{ab}$ & 196.0 a & $2.61 \mathrm{a}$ & $13.3 \mathrm{c}$ \\
\hline & \multirow{2}{*}{ SA } & $\begin{array}{l}2012 \\
2013\end{array}$ & $\begin{array}{l}14.4 \\
14.7\end{array}$ & $\begin{array}{l}197.3 \\
216.1\end{array}$ & $\begin{array}{l}2.67 \\
2.64\end{array}$ & $\begin{array}{l}10.7 \\
12.9\end{array}$ \\
\hline & & Combined & $14.6 \mathrm{a}$ & $207.3 \mathrm{a}$ & $2.66 \mathrm{a}$ & $11.8 \mathrm{c}$ \\
\hline \multicolumn{2}{|c|}{ LSD at 0.05 (Combined) } & & 0.903 & 51.8 & 0.51 & 1.63 \\
\hline
\end{tabular}

See footnote of Table 4 . 


\section{Grains protein content}

As shown in Table 7, data presented that the protein content percentage of wheat grains was significantly increased as affected by the treatments of sulphuric acid, elemental sulphur and gypsum compared to the control while, there was no significant difference between SA, ES, G1 and G2 treatments. This relative effect could be clarified the effect of sulphuric acid on enhancing the growth of wheat and improving the fertility of the studied soil compared with the low rate of gypsum (G1). The highest value of protein due to the treatment of sulphuric acid corresponded $64.4 \%$ increase over control. These results are in agreement with those obtained by Khan et al. (2007).

Respecting protein yield, it can be seen from results that there were no significant differences between the applications. Highest value $\left(207 \mathrm{~kg} \mathrm{fed}^{-1}\right)$ of protein yield was obtained due to addition of sulphuric acid which gave the highest nitrogen content and grain yield. Regarding the effect of the treatments it is can be arranged as follows: $\mathrm{SA}>\mathrm{ES}>\mathrm{G} 2>\mathrm{G} 1>$ control.

\section{Conclusion}

From the above mentioned results, it can be concluded that gypsum, sulphuric acid or elemental sulphur applications had decreased the hazard effect of salinity, in addition to favorable effect on growth and availability of chemical composition to wheat plants grown on saline soils. Sulphuric acid treatment was superior for enhancing the productivity and wheat quality than the other amendments used in the current study. This effect seemed to be dependent on soil properties that improving the buffering capacity and native nutrient content. Also, the favorable effect of soil amendments were referred to their influence on reducing soil $\mathrm{pH}$, improving soil structure and increasing the availability of the studied nutrients in soil. Therefore, it is recommended that farmers can apply the studied sulphur materials for increasing the productivity of wheat crop with good seed quality under saline soil conditions.

\section{References}

Abdel-Fattah, M.K. (2012) Role of gypsum and compost in reclaiming saline-sodic soils. J. Agric. and Veterinary Sci. 1(3): $30-38$.

Ahmed, S., Ghafoor, A., Qadir, M. and Aziz, M.A. (2006) Amelioration of a calcareous saline-sodic soil by gypsum application and different crop rotations. International $J$. Agric. and Biology 8 (2): 142 - 146.

Ali, R., Khan, M.J. and Khattak, R.A. (2008) Response of rice to different sources of sulphur (S) at various levels and its residual effect on wheat in rice-wheat cropping system. Soil Environment 27 (1): 131-137.

Ali, A., Arshadullah, M., Ishtiaq, S. and Mahmouud, I.A. (2012) Effect of different levels of sulphur on the productivity of wheat in a saline sodic soil. Soil Environ. 31(1): $91-95$.

Egypt. J. Soil Sci. 53, No. 2 (2013) 
Amezketa, E., Aragues, R. and Gazol, R. (2005) Efficiency of sulphuric acid, mined gypsum and two gypsum by-products in soil crusting prevention and sodic soil reclamation. Agronomy J. 97: 983-989.

Badr, Z., Ali, A., Salim, M. and Niazi, B.H. (2002) Role of sulphur for potassium / sodium ratio in sunflower under saline conditions. Helia 25 (37): 69-78.

Bates, L.S., Waldren, R.P. and Teare, I.D. (1973) Rapid determination of proline for water stress studies. Plant and Soil 39: 305-307.

Bello, W.B. (2012) Influence of gypsum application on wheat (Triticium aestivum) yield and components on saline and alkaline soils of Tigray region, Ethiopia. Greener J. of Agric. Sciences 2 (7): 316-322.

Blake-Kalff, M.M.A., Hawkesford, M.J., Zhao, F.J. and McGrath, S.P. (2000) Diagnosing sulphur deficiency in field grown oilseed rape (Brassica napus L.) and wheat (Triticium aestivium L.). Plant and Soil 225 (1-2): 95-107.

Choudhary, O.P., Ghuman, B.S., Singh, B., Thuy, N. and Buresh, R.J. (2011) Effects of long-term use of sodic water irrigation, amendments and crop residues on soil properties and crop yields in rice-wheat cropping system in a calcareous soil. Field Crops Research 121 (3): 363-372.

De Kok, L.J., Castro, A., Durenkamp, M., Stuiver, C.E.E., Westerman, S., Yang, L. and Stulen, I. (2002) Sulphur in plant physiology. Proceedings No. 500, The International Fertiliser Society, New York, pp. 1 -26.

Dick, W.A., Kost, D. and Chen, L. (2008) Availability of sulphur to crops from soil and other sources. Sulphur: A Missing Link between Soils, Crops and Nutrition: In: “Agronomy Monograph" 50, J. Jez, (Ed.), ASA-CSSA-SSSA. pp. 59-82.

Duke, S.H. and Reisenaue, H.M. (1986) Roles and requirements of sulphur in plant nutrition. In: "Sulphur in Agriculture", M.A. Tabatabai (Ed.), pp.124-168, Agronomy Series No. 27, American Society of Agronomy, Madison, Wisconsin, USA.

El-Kouny, H.M. (2009) Growth and quality response of sugar beet (Beta vulgaris L.) grown on calcareous soil to compost, elemental sulphur and nitrogen applications. Egypt. J. Soil Sci. 49 (4): 505 - 518.

El-Refaie, G. and Fahmy, H. (2005) Environmental, Agriculture and Socio-Economical Consideration for Non -Conventional Water Resources in Egypt. Natural resources development: SOCIO-Economic and Environmental Aspects. Drainage Research Institute, National Water Research Center, Egypt.

FAO (2011) Food and Agric. Organization of the United Nations Statistical.

Farook, A. and Khan, M.D. (2010) Response of mineral nutrient of rice to sulfidic material as sulphur fertilizer. Nature and Science J. 8 (8): 31-40.

Ghaudhry, M.R. (2001) Gypsum efficiency in the amelioration of saline-sodic soils. Int. J. Agric. Biol. 3: 276-280 
Haq, I., Muhammed, B. and Iqbal, F. (2007) Effect of gypsum and farmyard manure on soil properties and wheat crop irrigated with brackish water. Soil \& Environ. 26 (2): $164-171$.

Jena, D. and Kabi, S. (2012) Effect of gromor sulphur, bentonite sulphur pastilles on yield and nutrient uptake by hybrid rice- potato- green gram cropping system in an inceptisol. International Research J. of Agric. Sci. and Soil Sci. 2 (5): 179-187.

Khan, H.R., Syeed, S.M.A., Ahmed, F.A., Shamim, H.M., Oki, Y. and Adachi, T. (2007) Response of sunflower to sulfidic materials and magnesium sulfate as sulphur fertilizer. J. Bio. Sci. 7 (6):888 - 895.

Klute, A. (1986) "Methods of Analysis. Part 1, Soil Physical Properties", ASA and SSSA, Madison, WI.

Mahmood, A.M., Yazdanpanah, N., Sinobas, L.R., Pazira, E. and Neshat, A. (2013) Reclamation of calcareous saline sodic soil with different amendments (I): Redistribution of soluble cations within the soil profile. Agric. Water Management 120:30 - 38 .

Markus, D.K., Mckinnon, J.P. and Buccasuri, A.S. (1982) Automated analysis of nitrate and ammonium nitrogen in soils. New Jersey. Agric. Exp. Sta. 151: 17 - 84 .

Mazhar, A.A.M., Mahgoub, M.H. and Abd El-Aziz, N.G. (2011) Response of Schefflera arboricola L. to gypsum and sulphur application irrigated with different levels of saline water. Australian J. of Basic and Applied Sci. 5 (10): 121 - 129.

Ministry of Public Works (1998) Defining El-Salam Canal Development Project. (West and East Suez canal).

Mostafa, M.M. (2001) Nutrition and productivity of broad bean plant as affected by quality and source of irrigation water. Zagazig J. Agric. Res. 28 (3): 517 - 532.

Page, A.L. (1982) "Methods of Soil Analysis. II: Chemical and Microbiological Properties”, $2^{\text {nd }}$ ed., Soil Sci. Am. Inc., Madison, U.S.A.

Poraas, M.M.E., Sallam, A.M., Shaban, Kh.A.H. and Abou El-Defan, T.A. (2009) Using of some soil amendments and $\mathrm{N}_{2}$-fixer bacteria in improving the quality and yield of wheat as some characteristics of Sahl El-Tina saline soil (North Sinai). Egypt. J. Soil Sci. 49 (2): 255 - 270.

Pratiksha, M.V., Neha, T. P., Indu, B.P. and Amar, N.P. (2010) Implications of calcium nutrition on the response of Butea monosperma (Fabaceae) to soil salinity. Anales de Biología 32: 15-27.

Rasouli, F., Pouya, A.K. and Karimian, N. (2013) Wheat yield and physic-chemical properties of a sodic soil from semi-arid area of Iran as affected by applied gypsum. Geoderma 193-194: 246-255.

Russell, D. F. (1994) MSTAT-C v.2.1 (computer based data analysis software). Crop and Soil Sci. Department, Michigan State University, USA.

Egypt. J. Soil Sci. 53, No. 2 (2013) 
Ryan, J., Garabet, S., Harmsen, K. and Rashid, A. (1996) A soil and plant analysis "Manual Adapted for the West Asia and North Africa Region", 140p. ICARDA, Aleppo, Syria.

Sabir, G.K., Haq, H., Abdul Malik, Muhammad, J.K. and Naveedullah (2007) Effect of various levels of gypsum application on the reclamation of salt affected soil grown under rice followed by wheat crop. Sarhad J. Agric. 23 (3): 675-680.

Sadiq, M., Hassan, G., Mehdi, S.M., Hussain, N. and Jamil, M. (2007) Amelioration of saline-sodic soils with tillage implements and sulphuric acid application. Pedosphere 17(2): 182-190.

Saric, M.R., Kostroi, T.C. and Geric, I. (1967) "Chlorophyll Determination", Univ. Noven Sadu Prakitikum is Kiziologize Bilijaka Beogard, Haucna, Anjiga.

Scherer, H.W. (2001) Sulphur in crop production. European Journal of Agronomy 14 (2): $81-111$.

Soltanpour, N. (1985) Use of ammonium bicarbonate-DTPA soil test to evaluate elemental availability and toxicity. Soil Sci. Plant Anal. 16 (3): 323 - 338.

Tan, H., Rulin, X., Liuqiang, Z. and Jinping, L. (2000) Effect of various sulphur sources on yield and soil sulphur balance in a rice-rice cropping pattern in Guangxi province. Better Crops International J. 14(2): 24-25.

USDA (1954) Diagnosis and improvement of saline and alkali soils. Agriculture Hand Book, No. 60, US Gov., Printing Office, Washington.

Zhao, F.J., Salmon, S.E., Withers, P.J.A., Monaghan, J.M., Evans, E.J., Shewry, P.R. and McGrath, S.P. (1999) Variation in the bread making quality and mineralogical properties of wheat in relation to sulphur nutrition under field conditions. J. of Cereal Sci. 30 (1): 19-31.

Zia, M.H., Ghafoor, A. and Boers, S.Th.M. (2006) Comparison of sulphurous acid generator and alternate amendments to improve the quality of saline-sodic water for sustainable rice yields. Paddy Water Environment 4: 153-162.

(Received 19/9/2013

accepted 25/12/2013) 


\section{إنتاجية القمح وإمتصاص العناصر الغذائية بعد تثبيط الإجهاد الناتج

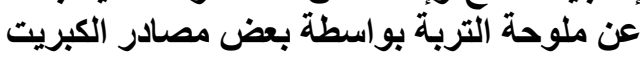

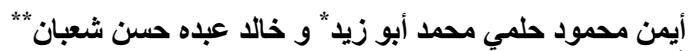

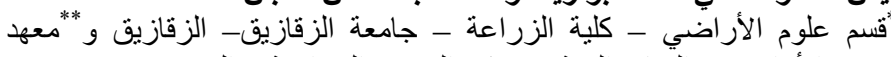 بحوث الأر اضي و المياه و البيئة ـ مركز البحوث الزراعة الزر اعية ـ الجيزة- مصر.}

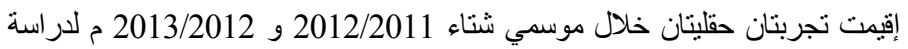

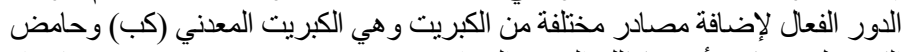

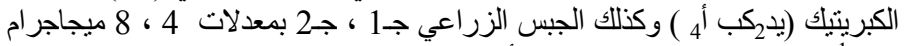

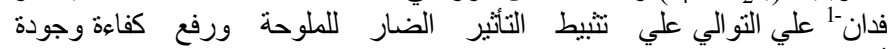

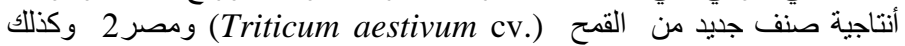

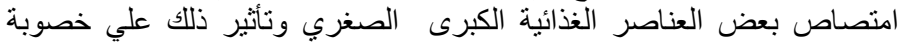

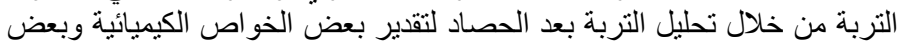

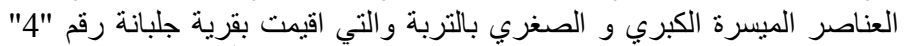
بمنطقة سهل الطينة بمحافظة شمال سيناء، ويمكن تلخيص التربة أهم النتائج المتحصل

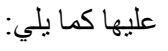

• كانت أعلي القيم المتحصل عليها لمحصول القمح ومساهماتة وكذلك لجودة

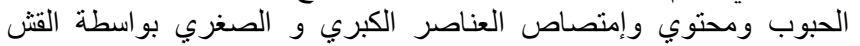

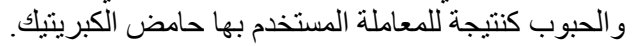

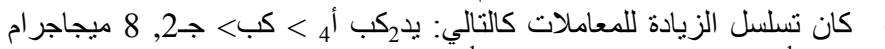

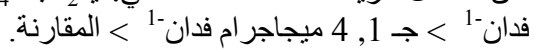

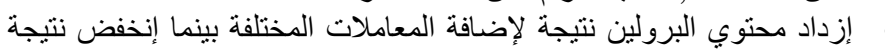

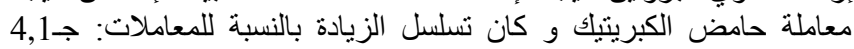

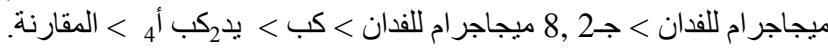

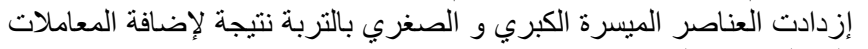
المختلفة تحت الدر اسة.

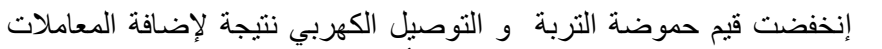

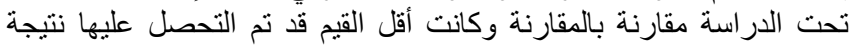

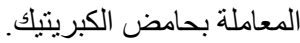

كانت المعاملة بحامض الكبريتيك هي الأحسن علي الإطلاق مقارنة بباقى الإكى

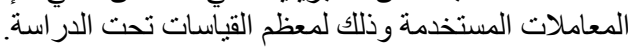

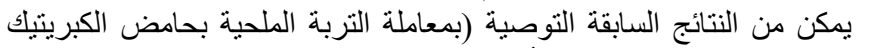

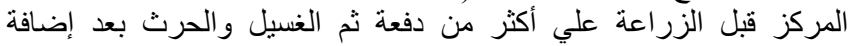

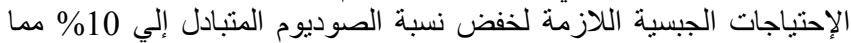

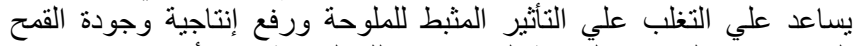

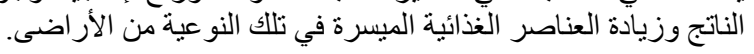

